University of Nebraska - Lincoln

DigitalCommons@University of Nebraska - Lincoln

Publications from USDA-ARS / UNL Faculty

U.S. Department of Agriculture: Agricultural

Research Service, Lincoln, Nebraska

January 2008

\title{
My biomass, your biomass, our solution
}

Wallace Wilhelm

University of Nebraska-Lincoln, wwilhelm1@unl.edu

Follow this and additional works at: https://digitalcommons.unl.edu/usdaarsfacpub

Part of the Agricultural Science Commons

Wilhelm, Wallace, "My biomass, your biomass, our solution" (2008). Publications from USDA-ARS / UNL Faculty. 215.

https://digitalcommons.unl.edu/usdaarsfacpub/215

This Article is brought to you for free and open access by the U.S. Department of Agriculture: Agricultural Research Service, Lincoln, Nebraska at DigitalCommons@University of Nebraska - Lincoln. It has been accepted for inclusion in Publications from USDA-ARS / UNL Faculty by an authorized administrator of DigitalCommons@University of Nebraska - Lincoln. 
W.W. Wilhelm, USDA-ARS, Lincoln, Nebraska, USA

Published online in Wiley InterScience (www.interscience.wiley.com); DOI: 10.1002/bbb.53; Biofuels, Bioprod. Bioref. 2:8-11 (2008)

$\mathrm{T}$ he USA is pursuing an array of renewable energy sources to reduce reliance on imported fossil fuels and to reduce greenhouse gas emissions. Biomass energy and biomass ethanol are key components in this pursuit. Vast amounts of biomass feedstock will be needed to produce sufficient ethanol to meet any of the numerous target production goals. The Billion Ton Vision suggests one billion tons of biomass is needed annually to meet the ' $30 \times 30$ ' goal (to replace $30 \%$ of 2004 levels of fossil transportation fuel use with ethanol by the year 2030). Great advances in technology will be required to produce this enormous quantity of biomass sustainably. These advances will not come about through ill-coordinated, competitive efforts. On the contrary, the problem of sustainably meeting the biofuel feedstock demand while continuing to meet traditional demands for agricultural output is so great that we need to focus all our energies on establishing complementary public energy policy based on facts and candid analysis; on crafting cooperative, coordinated energy goals across agencies; and on creating enthusiastic, dedicated teams of researchers and educators to develop and deploy existing and new technologies.

\section{Getting the message}

Several months ago a message arrived from colleagues describing their efforts and successes in developing alfalfa (Medicago sativa L.) as a biomass energy feedstock. The information got my defensive juices flowing. At that time
I had been working for several years to persuade the biomass ethanol industry to consider the critical importance of soil quality and long-term crop-production capability when developing a roadmap for our bio-energy future. My position was, and continues to be, that we must acknowledge and plan for the use of crop biomass as an essential soilmanagement input. Crop residue is the major source of carbon entering the soil-carbon cycle. It is transformed into soil organic carbon (SOC) by the action of soil microbes. In turn, SOC is central to many of the functions and properties characteristic of productive soils. ${ }^{1}$ The amount of crop residue required to maintain SOC can be substantial. ${ }^{2}$ In a corn (Zea mays L.)-soybean [Glycine max (L.) Merr.] rotation with aggressive tillage (moldboard plow), the corn stover input needed to sustain SOC has been estimated to be $12.5 \mathrm{Mg} \mathrm{ha}^{-1}$ (5.6 ton $\left.\mathrm{ac}^{-1}\right) .^{3}$ In addition, crop biomass is an essential component in the battle against soil erosion. ${ }^{4}$ These demands for crop biomass must be satisfied before we attempt to collect crop residues and remove biomass from the land as a feedstock for transportation fuel production, if production is to be sustained. My focus was on use of crop residues, especially corn stover.

My defensive thoughts centered on the desire for 'my' biomass, corn stover, to be the epicenter of the renewable fuel earthquake; the feedstock that would eventually solve the current fossil fuel-greenhouse gas problem - and, dare I admit it, make my reputation. How could someone suggest they had a source of biomass, other than crop residues, that

Correspondence to: W.W. Wilhelm, USDA-ARS, Agroecosystem Management Research Unit, 117 Keim Hall,

University of Nebraska, Lincoln, NE 68583-0934, USA. E-mail: Wally.Wilhelm@ars.usda.gov

${ }^{\dagger}$ This article is a US Government work and is in the public domain in the USA.

(अ)WILEY

InterScience 
may offer a better means of producing feedstock for the biomass ethanol industry?

I recognize these thoughts, while not illogical from a selfish point of view, were completely inappropriate. Considering my previous presentations and writings ${ }^{5}$ - including recent admonitory $^{6}$ assessment of the Billion Ton Vision ${ }^{7}$ - some might assume that I would prefer no crop residues be collected as feedstock. However, my real intention was, and remains, to create a biomass ethanol industry that is based on sustainable production and harvest of feedstock.

After reading the message I was upset enough to compose a message of my own - but I did not know to whom it should be addressed. So I just composed, edited - and thought. In the end I came to realize that I was the person who most needed to receive my message. The remainder of this commentary is based on that initial thinking and writing, modified by about a year of broadened appraisal.

\section{The time for competition has passed}

In 2006 and 2007, President Bush specifically mentioned (corn) stalks and the need to make increased use of biomass as one of several solutions to the USA's energy dilemma. ${ }^{8,9}$ These statements placed greater focus on the role of agriculture in energy production than at any time since World War II, perhaps than at any time in the past. ${ }^{10}$ Today, everyone is looking for ways to position themselves to reap benefit from the current enthusiasm for renewable fuels, bioenergy, and biomass ethanol.

As stated by Fales et al., in a recent CAST Commentary, ${ }^{11}$ several biomass ethanol production goals with varying targets and timeframes have been publicized. These range from the ' 20 in 10' plan established by the President's Advanced Energy Initiative, which aims to replace $20 \%$ of our gasoline consumption with renewable fuels in 10 years, ${ }^{8}$ to the ' $30 \times 30$ ' target, which is to replace $30 \%$ of the US motor fuel consumption with renewable fuels by $2030 .{ }^{12}$ Although the horizons and goals differ, they all align forming a series of consecutive goals on a similar trajectory. All of these fuel or energy production goals can be translated into a feedstock demand determined by the conversion rate between biomass and ethanol. Although conversion technology is advancing rapidly, $334 \mathrm{~L}$ ethanol $\mathrm{Mg}^{-1}$ dry biomass $\left(80 \mathrm{gal} \mathrm{ton}^{-1}\right)$ is a broadly accepted value at this time, ${ }^{13} 20-30 \%$ of US motor fuel use [530 billion L year ${ }^{-1}$ (140 billion gal year $\left.{ }^{-1}\right)$ ] is 106 to 159 billion L (28 to 42 billion gal) of fuel. Correcting for energy content differences between gasoline and ethanol, this is a feedstock demand of 450-680 million Mg (500-750 million tons) annually ${ }^{11}$.

Obviously the agricultural and forest industries have a mammoth task before them if we are to generate this huge amount of biomass in addition to meeting current demand. The Billion Ton Vision ${ }^{7}$ has established expectations on the part of the biomass industry, the public, and Congress that we will be able to sustainably produce $30 \%$ of the nation's vehicle fuel from biomass by 2030, and even the misplaced belief that we already have the technology to do so. In fact, we must make great advancements in technology to supply the needed biomass on an annual basis, particularly if we are to do so sustainably. ${ }^{14}$ These required advances will be in all aspects of bioenergy - biomass production, feedstock storage and transport efficiency, conversion technology, distribution capacity, efficiency in energy use, and conservation. ${ }^{11}$

We will also need to expand our ideas about what biomass is considered feedstock. Bluntly, all forms of biomass (crop residue, dedicated energy crops from both agricultural and forest, municipal, industrial, and demolition wastes, etc.) will be essential to produce the amount of feedstock suggested in the Billion Ton Vision, ${ }^{7}$ but the major source will be agriculture. The Vision ${ }^{7}$ estimates that agriculture has the potential to contribute 0.907 billion $\mathrm{Mg}$ ( 1 billions tons) of biomass annually for ethanol production. The report goes on to state that this massive production and collection of dry matter can be done sustainably, without negative impacts on air, water, or soil resources and without hampering the ability of agriculture to provide traditional outputs of food and feed.

And there I was getting defensive about colleagues suggesting that other biomass had advantages over corn stover. The most astounding point in this examination of my reaction is that I felt threatened by other feedstocks being suggested as contributors to satisfying this truly enormous demand for biomass - that I saw them as competitors. Achieving any of the renewable energy goals will require all types of currently produced biomass and more. The pressing question is, 'Can we create the technology to produce the needed feedstock in a sustainable manner?' not 'Will my 
feedstock be the most important?' The time for competition has passed. Challenges abound. No single biomass, no single technology holds the key to achieving our renewable energy goals. Biomasses and technologies must be cumulative and synergistic to achieve success. The time for cooperation and mutual support is upon us.

\section{The way forward}

As a research community, we need to establish and share goals and develop enthusiastic, committed teams dedicated to creating the best technology and finding the best solutions to energy problems. As policy-makers, we need to establish unified and complementary, congruent goals within and across agencies and political jurisdictions. As investors, we need to explore and finance alternatives, but we must be realistic and discerning as we investigate ventures to support - not following the latest hype, but making honest evaluations of risk and potential before investing. As citizens, we must demand public policy based on facts and appropriate analysis and energy policy based on science, economic reality, and conservation in addition to advances in production technology.

The Council for Agricultural Science and Technology $(\mathrm{CAST})^{11}$ has listed a number of advances in technology, and supporting policy, needed to move the biofuels industry toward the established goals. ${ }^{8,9,12}$ They specifically point to the importance of coordinating the expansion of the supply of feedstock with the demand for that feedstock by the conversion facilities. To sustainably expand supply, new species, new cultivars of these species and new management practices for the existing and new species will be required. In all of these cases, it will be important to improve radiation-use efficiency. Thirty years ago Monteith ${ }^{15}$ provided prophetic discussion of changes in radiation-use efficiency with change in species, climate, or management practices, offering estimates of theoretical maximum production levels for several crops. These approximations are 100 times current production levels. Many factors contribute to the gap between theoretical and current production levels, and each of these factors represents an opportunity for a technological advance that may expand biomass production from existing land and input resources. Long et al., ${ }^{16}$ present a detailed, thought-provoking discussion of the potential to increase crop (grain) yield, building on Monteith's comments on radiation use efficiency. Though the comments by both Monteith ${ }^{15}$ and Long et al., ${ }^{16}$ focus on crop grain yield, most apply to biomass yield as well.

Some of the technologies that could be used to expand biomass production already exist. For example, the need for crop residue to control erosion and maintain soil carbon limits biomass available for biofuel production. ${ }^{2}$ Adding a winter cover crop to a summer annual cropping system would add ground cover, in the form of the cover crop canopy, and would reduce erosion. In addition, the winter crop canopy would increase interception, capture, and use of solar radiation during that part of the year when no crop is normally grown on the land and, in turn, increase biomass production - reduced carbon that could be returned to the soil or used as livestock feed. Several other technologies exist or will be perfected in the near future, including the optimization of planting patterns, planting dates, crop rotations and crop sequences and improved methods for water ${ }^{15}$ and nutrient application ${ }^{17}$ that minimize or eliminate crop stress. Meanwhile, genetic manipulation and breeding technologies will need to be used to produce cultivars that are optimized for the capture of radiation, water and nutrients and for metabolic and physiological efficiency. For example, enhanced metabolic efficiency or eliminated inefficiency (photorespiration) may be achieved by introducing $\mathrm{C}_{4}$ metabolism into existing $\mathrm{C}_{3}$ crops. ${ }^{16}$ Even outlandish notions such as adding pigments that absorb green light to the photosynthetic apparatus, adding to the range of radiant energy that can be captured and used to produce biomass, should be explored.

\section{A change in attitude}

In the previous paragraphs several key ideas have been highlighted: teamwork, enthusiasm, and dedication. The entire bioenergy effort needs a greater feeling of team, a greater sense of common goal, a commitment to achieving team objectives by generating enthusiasm for the work and a culture of support for all efforts contributing to the common goal. The time of feeling defensive, of wasteful competition, and of waiting for new and larger discoveries of fossil fuels has passed. As a nation, as a global community, we must accept the challenges presented by the growing demand 
for renewable energy and the need to reduce greenhouse gas production. We have the opportunity to channel the euphoria surrounding renewable energy into monumental advances in technology and conservation, enabling real progress in moving away from an economy based on fossil fuels toward one based on bio- or renewable energy.

I have changed my attitude. I hope we all have. I am no longer defensive in discussing the array of potential feedstocks. I have moved from discussions tilted by thoughts of whose feedstock is best to how we can sustainably produce enough feedstock to meet the massive projected demand, regardless of source.

\section{Acknowledgements}

This paper is a joint contribution of the US Department of Agriculture's Agricultural Research Service and the Agricultural Research Division of the University of Nebraska. This publication is based upon work supported by the Agricultural Research Service under the ARS REAP effort.

\section{References}

1. Sikora LJ and Stott DE, Soil organic carbon and nitrogen, in Methods for Assessing Soil Quality, Special Publication Number 49 ed by Doran JW and Jones AJ. Soil Science Society of America, Madison, Wisconsin, USA, pp 157-167, (1996).

2. Wilhelm WW, Johnson JM-F, Karlen DL and Lightle D, Corn stover to sustain soil organic carbon further constrains biomass supply, Agron $J$ 99:1665-1667 (2007).

3. Johnson JM-F, Reicosky D, Allmaras R, Archer D and Wilhelm WW, A matter of balance: conservation and renewable energy, $J$ Soil Water Cons 61:120A-125A (2006).

4. Soil Quality National Technology Development Team, Crop residue removal for biomass energy production: effects on soils and recommendations, Technical Note 19, NRCS, Greensboro, NC 27401 (2006), available at http://soils.usda.gov/sqi/management/files/sq_atn_ 19.pdf [November 22, 2007]

5. Wilhelm WW, Johnson JM-F, Hatfield JL, Voorhees W and Linden DR, Crop and soil productivity response to corn residue removal: A literature review, Agron J 96:1-17 (2004).

6. Wilhelm WW, Varvel GE, Karlen DL, Johnson JM-F and Baker JM, Crop residue as feedstock for the new bio-economy: opportunities and roadblocks, in Annual meeting abstracts [CD-ROM]. ASA, CSSA, and SSSA, Madison, Wisconsin, USA (2006).

7. Perlack RD, Wright LL, Turhollow AF, Graham RL, Stokes BJ and Erbach DC, Biomass as feedstock for a bioenergy and bioproducts industry: the technical feasibility of a billion-ton annual supply DOE/GO-102005-2135 and ORNL/TM-2005/66. Oak Ridge National Laboratory, Oak Ridge, Tennessee (2005).

8. National Economic Council, Advanced Energy Initiative 9554, Office of the President, Washington, DC (2006).

9. Bush GW, 2007 State of the Union Address. (2007). Available at http:// www.whitehouse.gov/stateoftheunion/2007/initiatives/sotu2007.pdf [May 30, 2007].

10. Vogel KP, Energy production from forages (or American agriculture-back to the future) J Soil Water Cons 51:137-139 (1996).

11. Council for Agricultural Science and Technology (CAST), Convergence of agriculture and energy: II. Producing cellulosic biomass for biofuels, CAST Commentary QTA 2007-2, CAST, Ames, lowa (2007).

12. Foust TD, Wooley R, Sheehan J, Wallace R, Ibsen K, Dayton D et al., A national laboratory market and technology assessment of the $30 \times 30$ scenario. NREL/TP-510-40942, draft publication, March 2007. ('Cellulosic Ethanol Production', Section 4, available at http:// $30 \times 30$ workshop.biomass.govtools.us/documents/30x30Section4Only. PDF [July 2, 2007].

13. Dien BS, A primer for lignocellulose biochemical conversion to fuel ethanol, in Proceedings of the 5th International Starch Technology Conference, ed by Rausch K, Singh V, and Tumbleson M, June 3-6, 2007, University of Illinois, Urban, IL, USA. pp 87-95 (2007).

14. Council for Agricultural Science and Technology (CAST), Convergence of agriculture and energy: Implications for research and policy, Commentary QTA 2006-3. CAST, Ames, lowa, (2006).

15. Monteith JL, Climate and the efficiency of crop production in Britain. Phil Transactions of the Royal Society of London 281:277-294 (1977).

16. Long SP, Zhu X-G, Naidu SL and Ort DR, Can improvement in photosynthesis increase crop yields? Plant Cell Environ 29:315-330 (2006).

17. Cassman KG, Ecological intensification of cereal production systems: Yield potential, soil quality, and precision agriculture. Proceedings of the National Academy of Science 96:5952-5959 (1999).

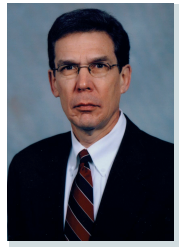

W.W. Wilhelm, USDA-ARS, Lincoln, Nebraska, USA Wally Wilhelm is a research plant physiologist with the US Department of Agriculture-Agricultural Research Service (USDA-ARS) Agroecosystems Management Research Unit and an adjunct professor of agronomy and horticulture at the University of Nebraska, Lincoln. He leads the Renewable Energy Assessment Project (REAP), a multi-location ARS effort to develop tools and cropping practices that maximize sustainable harvest of biomass as bioenergy and bioproduct feedstocks. He has worked to help the cellulosic ethanol industry understand that crop residues are not wastes of grain production and that residues play a vital role in maintaining soil functions and preserving the capacity of agricultural lands to produce food, feed, and fiber when returned to the soil. 